\title{
Influence of Caloric Expenditure on Postprandial Triglyceride and Glucose Responses Following a High-Carbohydrate Meal
}

James Rowe, Heidi Bistrup, Kelley Henry, Melinda Villarreal, Kyle D. Biggerstaff, Vic Ben-Ezra

Texas Woman's University

Int J Exerc Sci 2(1): S5, 2009. Purpose: To examine the effects of aerobic exercise expending 350 and $700 \mathrm{kcal}$ of energy on postprandial triglyceride (Tg) and glucose responses following a high carbohydrate $(\mathrm{CHO})$ meal. Methods: Non-active individuals $(\mathrm{n}=9$ women $/ 4$ men; age $=22.8 \pm 3.7 \mathrm{yrs} ; \mathrm{Ht}=169 \pm 10.4 \mathrm{~cm} ; \mathrm{Wt}=75.7 \pm 22.4 \mathrm{~kg} ; \mathrm{BMI}=26.1 \pm 5.8$ $\mathrm{kg} / \mathrm{m} 2 ; \mathrm{VO} 2 \mathrm{max}=34.1 \pm 6.9 \mathrm{ml} / \mathrm{kg} / \mathrm{min}$ ) completed three trials in a random order: 1 ) control trial, 2) single exercise session expending $350 \mathrm{kcal}$ (EX350), and 3) single exercise session expending $700 \mathrm{kcal}$ (EX700). Exercise consisted of treadmill walking at $60 \% \mathrm{VO} 2$ max until 350 and $700 \mathrm{kcal}$ of energy had been expended. The control session consisted of seated rest. The morning after each experimental session, a fasting (12hr) blood sample was collected followed by consumption of a high-CHO liquid meal $(2.44 \mathrm{~g} / \mathrm{kg}$ of fat free mass (CHO), $0.33 \mathrm{~g} / \mathrm{kg}$ FFM fat, and $0.56 \mathrm{~g} / \mathrm{kg}$ FFM protein. Blood was collected again at 1, 2, 3, 4, 5, and 6 hrs post-meal and analyzed for $(\mathrm{Tg})$ and glucose concentrations. The areas under the curve (AUC) were calculated for both (Tg) and glucose concentrations. A repeated measures ANOVA was used to determine statistical significance $(p<0.05)$. Results: Baseline glucose concentrations were not different between trials $(p=0.71)$. Postprandial AUC for glucose concentrations were not different between trials $(\mathrm{p}=0.38)$. Baseline $\mathrm{Tg}$ concentrations were not altered with exercise $(p=.94)$ of $350 \mathrm{kcal}(102.7 \pm 77.1 \mathrm{mg} / \mathrm{dl})$ or $700 \mathrm{kcal}(112.2 \pm 80.6 \mathrm{mg} / \mathrm{dl})$ when compared with rest $(115.3 \pm 113.9 \mathrm{mg} / \mathrm{dl})$. Postprandial $\mathrm{Tg}$ concentrations following rest $(937.3 \pm$ $928.4 \mathrm{mg} / \mathrm{dl})$ were not altered $(\mathrm{p}=0.37)$ following exercise of $350 \mathrm{kcal}(807.1 \pm 605.1$ $\mathrm{mg} / \mathrm{dl})$ or $700 \mathrm{kcal}(867.3 \pm 672.6)$. Conclusion: The glucose and Tg responses following a high-CHO meal were unaffected by a prior exercise session. These results are in contrast to previous investigations that have used high-fat test meals demonstrating that a single bout of exercise reduces the postprandial Tg response. Substantial intersubject variability was seen in the postprandial $\mathrm{Tg}$ responses following exercise ranging from reductions of $27.4 \%$ to increments of $17.4 \%$. This study was supported by Texas Woman's University's Research Enhancement Program.

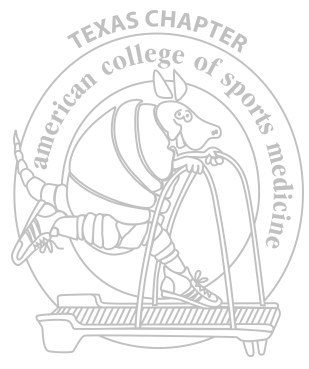

S5 http://www.intjexersci.com 